\title{
College English Multimedia Teaching Problems and Countermeasures
}

\author{
Lina Zhao', Xichun Han ${ }^{2}$ \\ ${ }^{1}$ International Education Department of Peihua University, Xi'an Shaanxi, China \\ ${ }^{2}$ Science and Engineering Department of Xi'an Radio and Television University, Xi’an Shaanxi, China
}

Keywords: Multimedia Teaching, College English

\begin{abstract}
Multimedia Teaching accounted for the dominant position in modern teaching, for college English classroom, the multimedia of English teaching has its advantages, but there are some drawbacks. In order to make the English Teaching achieve good result. It will lay the foundation of the use of multimedia teaching used in the college English class.
\end{abstract}

\section{Introduction}

This paper is how to use the multimedia in the right way, and it can get good result for students learning in college English. Now using several parts to express the meaning in this paper: (1) First is the multimedia's feature, introducing its character in the class, then according to its feature to use in the class. (2) College English situation and difference between traditional and model education, if the education will be improved highly, using multimedia is a good method for college English learning. (3) How to use multimedia in the right way and get the higher teaching result is complex thing. so it demands every teacher and student to use it appropriately, not using multimedia blindly. At last it can help everyone improve college English quickly and effectively.

\section{Multimedia Teaching's feature}

2.1 Nowadays, teaching technology of multimedia is developed quickly, It is more and more widespread in teaching process. Multimedia will fell abstract theory and actual operation together, It has already become a type of teaching system. If you want to improve the teaching efficiency, must use more methods to stimulate student's learning interest and improve their learning level. It demands the teacher to use multimedia teaching in the class, and pay close attention to educational theory's development, then use advanced educational theory to guide your teaching jobs of multimedia, at last giving play to Multimedia Teaching's potential advantage, Properly using multimedia teaching to dispose the relationship between teachers, students and multimedia, another parts are traditional Teaching and Learning, content of courses and instructional mode's relation.

2.2 Multimedia is pointed that it uses disk, light disk, tap’s storage to transmit figure, words, voice and graph's information. Multimedia computer-assisted instruction use computer and variety multimedia to transmit information, then finishing objectives of model teaching. Its appearing visual result is through screen or projector to show figure, A pattern's adding voice as needed to distinct traditional teaching. It has integrated interaction, controlling character. So it makes multimedia have some many characters: Teaching information's volumize, Teaching information's bulk-storage memory, Learning contents' information, Teaching process' interaction and teaching information's network.

\section{Teaching and Learning of college English's current situation}

With educational reform and development, Traditional education has much malady, They pay attention to oral English and listening, wherever every primary school and middle school have improved it . But only through teachers and students' practice can't touch the level of speaking and understanding English's ability. If want to improve English teaching quality, must take full advantage of all kinds of teaching materials, and proceed character and sound image's lovely. By mean of 
watching phonograph and videotape's media, It can let students master English familiar with the ear and mouth. In modern times educational theory, method of improving teaching efficiency is about this: "The first is pursuing varied or novelty, the second is effectively using time reasonable, the third is explaining question from different angle”. So multimedia offers a good approach is that its purpose is to reach these teaching efficiency.

\section{Multimedia's teaching will bring teaching efficiency for college English.}

\subsection{Establishing simple, relaxed classroom, striving to improve teaching quality.}

Applying multimedia's teaching can strength student's learning interest. Inspiring their enthusiasm of learning. It is based on the students' strong interest, they focus on the classroom teaching, and they can interact with the teachers very well. In addition, the teachers can display the corresponding knowledge according to the text content during the teaching period. By watching video, students can think of themselves and grasp the priorities and tasks in the class. For example, when the teacher explained the fourth book of college English, it was about World War II. Hitler and Churchill was viewed through video in the history documentary. Another by watching the documentary, students not only looked back on history but also had a clearer understanding of historical figures and also have a good understanding of the article .What is more important is that the text's content is interesting, rich, not boring. so the students' interest in leaning is greatly improved.

\subsection{Breakthrough difficulties,the knowledge is difficult to be simple}

Using multimedia to make English teaching image, effectively and intuitively. Its animation effect is not replaced by other teaching methods, which can effectively concertize and visualize knowledge, simplifying difficulties and making it easier for students to understand, thus highlighting key points. Participle's use and Past Participle is a difficult knowledge point in English teaching. In order to explain the difference between the Present Participle and Past Participle, teachers can use multimedia technology to design a few images to practise, such as: the risen moon and the rising moon, boiling oil and boiled oil, First teachers showed students in English, the two verb forms in the dynamic sense in the difference, and then practise to consolidate with other image, another such as: A working woman, a broken cup, a sleeping child, a frightened girl, polluted air, etc. By this method the students will be able to understand the Present Participle and the Past Participle.

\subsection{Improving learning confidence and the speed of memory}

In English learning, remembering words has always been the students' problem. But how to improve the effect of remembering words effectively has long been a matter of deep thought, and now we know that memory is a constant repetition to remember. But because of time's problem, students can't use time to remember words, sentences, articles... In this case, multimedia can solve this problem. The combination of pictures, shapes and sounds makes it easy to remember the words, It can achieve the best effect of learning English.

\subsection{Enhancing the man-machine dialogue and improving the self-learning effect}

At present, English teaching emphasizes the individualized teaching and autonomous learning, and the computer can carry out the listening and training independently. Through reading, writing, translation and the characteristics of skills, teachers can be guided. So that the students are under the guidance of teachers, according to its own characteristics, level, time, choosing the appropriate learning content, a series of activities can be done with the help of computer, Improving their English comprehensive practical ability quickly, At last to achieve the best learning effect. 


\section{There are some disadvantages of multimedia in English teaching.}

\subsection{It shows that the speed is very fast, the students can't get some information and accept it passively.}

The concept of "people -oriented" is becoming more and more popular in the educational circle. Students are the subjects taught by the teachers and centered on students in the education process. We all know that teaching is not only taught by ourselves, but also the main role of students. We often notice that some teachers showed courseware too fast, students just watched pictures or music passively,. There is no time to think in our teaching process. In the use of multimedia teaching means that. It should not be ignored using multimedia display the text or conversation materials, only showing the scene and the audio language for student, It can't replace the students in English, teachers create scenarios for communicative practice, some can't replace the minds of students training. We should fully reflect student's initiative and creativity, When we make courseware.

\subsection{Multimedia's excessive use}

In the view of many teachers, they believe that more multimedia was used in English class, the better the teaching effect, the higher the student participation rate. In fact every class has its own characteristics, so the teaching method is used in each class differently. Some want to use multimedia, but some are not suitable. On the surface, the student are interested in it strongly. In fact, involuntary attention too much on students in the class, During the process of delivery, teaching information will be affected by interference similarly, A lesson's content should not be applied in the same class. With the use of multimedia technology to assist teaching training, First, the teaching materials should be made up the purpose and key points of teaching should be made clearly. On this basis, according to the teaching situation, the trainees, targeted, purposeful, selection of content, reasonable use of multimedia technology. Otherwise, just using the multimedia blindly, extensive use of animation, picture, music, etc. In the classroom, it is easy to divert student's attention, contrary to the teaching intention.

\subsection{Playing down the communication between teachers and students, the classes' atmosphere is so indifferent.}

The use of multimedia can use powerful information to simulate teacher's teaching behavior and complete part of teacher's work. But some teachers often let computers take the place of themselves, then teachers only act as operators, students follow the computer passively, teaching and learning are out of touch, the lectures become a lesson. It is obvious that the teaching of English text in the language lab that reflects this disadvantage. The student study by themselves, the teacher carries on the operation at the platform, but because each seat has a grid to separate, then some students will "do the private work", reducing the effect of the class, it is the bad affection in English learning. That will also reduce the communication between students and teachers, when a semester is over, students and teachers can't know each other, even not knowing the name of the students, In fact students can be remembered by the teachers is very important. Because he will have a kind of happiness in focusing on, and the teacher will be more in the students' heart, another side students will become more interested in learning and confidence.

\section{Effective improvement of the disadvantages of multimedia teaching and reasonable use of multimedia teaching}

Though college English multimedia teaching can enrich content of the text, efficiently and intuitively to achieve good teaching effect efficiently and in, but the disadvantages aspects need to be improved: (1) shorten playing time of the invalid in multimedia video, strengthen the effective knowledge repetition and fine. It is necessary to take the important knowledge into the multimedia as the type of picture,music, video. (2) For example, the process of using multimedia can take students to participate, talking about some allusions in the article, songs or stories that allow students to 
prepare in English ahead of time. In the process of teacher let the students put their own courseware and video display, which can improve the students' interest in learning effectively, and multimedia teaching has the interaction between teachers and students. (3) As for as possible let oneself explain the knowledge in the multimedia teaching by students in the form of interlocking, accepting knowledge passively and learning knowledge actively. It is only through such a change, using multimedia teaching can play its real value effectively, and make it a good service during the conclusion of college English teaching.

\section{Conclusion}

To sum up, the best teaching and learning's result can be produced by using modern multimedia. We should improve the efficiency teaching and the teaching quality of English, But in the process of using, we should pay attention to some problems and useful conditions for the effective teaching of college English.

\section{References}

[1] Liang Mu . Chao Rong Jia. A Practical Tutorial for Flash MX Courseware[M]. Tsinghua University Press, 2005 p11-13

[2] Wenfeng Hong. Yumei Liu. Bi Guangji Information Technology Education and Multimedia CAI Courseware [M]. Beijing Institute of Technology Press, 2006 p25-

[3] Wenqing Chen. Xiangdong wen. Gao yan. Principles and Fabrication of Li Hua Multimedia CAI Courseware [M]. Metallurgical Industry Press,2005 p40-43

[4] Yu Min Liu. Production and Preparation of Multimedia Materials of Wenbin Liang [M]. China National Defense Industry Press,2006 p56-57 